RESEARCH ARTICLE

\title{
EVALUATION OF RICE BASED CROPPING SEQUENCES FOR WATER SCARCE CONDITIONS OF PARAMBIKULAM ALIYAR COMMAND AREA OF TAMIL NADU
}

\author{
Sudhalakshmi $\mathbf{C}^{* 1}$, Rani $\mathbf{S}^{2}$ and Geethalakshmi V \\ ${ }^{1}$ Soil Science and Agricultural Chemistry, Coconut Research Station, Aliyarnagar- 642101 \\ 2Department of Agronomy, Tamil Nadu Agricultural University, Coimbatore-641 003 \\ ${ }^{3}$ Tamil Nadu Agricultural University, Coimbatore-641 003
}

\begin{abstract}
Field experiments were conducted at Coconut Research Station, Aliyarnagar during 2016 - 2019 to assess the performance of rice-based cropping sequences for water-scarce conditions of the Parambikulam Aliyar Project Command area of Tamil Nadu. Five cropping sequences viz., rice-sesame $\left(T_{1}\right)$, rice-groundnut $\left(T_{2}\right)$, rice- sunflower $\left(T_{3}\right)$, rice-castor $\left(T_{4}\right)$ and rice-black gram $\left(\mathrm{T}_{5}\right)$ were experimented adopting Randomized Block Design with each sequence replicated four times. Results revealed that compared to the other non-legume sequences experimented, the contents of $\mathrm{KMnO}_{4}-\mathrm{N}$ and organic carbon in the post harvest soil, productivity of rice and economic efficiency were higher in rice-black gram followed by rice-groundnut sequence. Ricecastor sequence recorded the highest land utilization efficiency of $76.7 \%$ and was the lowest in rice-black gram sequence (53.4\%). Rice equivalent yield was the highest on sequential cropping with sunflower (5755 kg ha-1) followed by groundnut $\left(5028 \mathrm{~kg} \mathrm{ha}^{-1}\right)$. Production efficiency was the highest in rice- groundnut ( $47.5 \mathrm{~kg} \mathrm{ha}^{-1}$ day $^{-1}$ ) followed by rice-castor $\left(42.5 \mathrm{~kg} \mathrm{ha}^{-1}\right.$ day $\left.{ }^{1}\right)$ systems. Net returns and benefit-cost ratio were higher in rice-sunflower and rice-black gram sequences followed by rice-groundnut and was the lowest in rice-sesame sequence. In terms of soil fertility, system productivity and economic returns, rice-sunflower, rice-black gram and rice-groundnut systems are highly remunerative for water-scarce conditions of Parambikulam Aliyar Command Area of Tamil Nadu.
\end{abstract}

Key words : Rice; Cropping Sequence; Rice Equivalent Yield; Net Returns; Production Efficiency; Economic Efficiency.

\section{INTRODUCTION}

Rice and wheat are the two important cereals that witnessed India to a dramatic switch over of food grain export in the 1990s from mere self-sufficiency in the 1980s. Rice has been the companion of humankind for more than 8000 years providing staple food to 2.5 billion people which may escalate to 4.6 billion by 2050 (Lampe, 1995). In India, its acreage spreads over 44.5 million hectares constituting $34 \%$ of the area under food crops and $42 \%$ under cereals, with a total production of 117.47 million tonnes and productivity of $2639 \mathrm{~kg} \mathrm{ha}^{-1}$. In Tamil Nadu, this domesticated crop is cultivated over 17.22 lakh hectares with a production of 64.54 lakh metric tonnes and productivity of $3748 \mathrm{~kg}$ $\mathrm{ha}^{-1}$ (GoTN, 2019). Rice production in the tropics is sensitive to climatic factors like temperature, rainfall, and solar radiation affecting the crop in various ways during different stages of its growth (Yoshida, 1978). The adverse impacts of climate change on rice production systems have been increasing over recent years (Matsushima et al., 1966).

Rice is a profligate user of water, and more than five tonnes of water is required to grow one kilogram of rice. The water use efficiency of rice is only $3.7 \mathrm{~kg} / \mathrm{ha} / \mathrm{mm}$ (Subbian et al., 2000), which is far less compared to the other predominant field crops known. Coimbatore is one of the agriculturally important districts of Tamil Nadu in which the majority of the agricultural lands are benefitted from the Parambikulam Aliyar Project (PAP), which is a major interstate multipurpose irrigation project. Rice, coconut, groundnut and vegetables are the principal crops of the command area with a total ayacut of 1.74 lakh hectares. Rice-rice-green manures is the predominant cropping system practised for ages by the farmers of the Anaimalai belt of PAP command because of the unprecedented irrigation water from the Aliyar reservoir. However, during 2016 and the years followed, the mean annual rainfall of the 
region was $59.4 \%$ less than the average annual rainfall of $808 \mathrm{~mm}$, which posed a significant impediment for rice cultivation. Several thousand acres of agricultural lands were kept barren for want of irrigation water. In the event of monsoon failure, Aliyar reservoir can support only one rice crop (Kharif) per year and the rice growers incur huge losses by sacrificing the second Rabi rice crop. Besides water scarcity, continuous rice cropping also resulted in other problems like a relatively low response of nitrogen $(\mathrm{N})$ fertilizers and slow mineralization rates as stated by Cassman et al. (1995) and Olk and Cassman (1995). Occurrence of second-generation problems such as over-mining of soil nutrients, the decline in factor productivity, reduction in profitability, lowering of ground-water table and build-up of pests including weeds, diseases and insects has been reported in continuous ricerice cropping system (Ray et al., 2009) signifying the importance of crop diversification. Due to the introduction of short and medium duration rice varieties, multiple cropping and the diversification of rice-based cropping system is possible with the inclusion of pulses, oilseeds and vegetables and this has been found more beneficial, providing enhanced productivity of the system and improved soil fertility status than cereal-cereal sequence (Kumpawat, 2001 and Sravan et al., 2015), in alleviating the poverty, employment generation, ensuring balanced food supply, and improving productivity and sustainability of the cropping systems (Sravan and Murthy, 2018).

Sahrawat (2004) reported the importance of grain legumes in rice-based rotations to enhance the decomposition of accumulated organic matter as against the slow decomposition rate in continuously waterlogged rice soils. Evidence accumulate stating that inclusion of pulses, oilseeds and vegetables in the system is more beneficial than cereals after cereals, and such inclusion in a sequence changes the economics of the crop sequences (Patra et al., 1989; Gangwar et al., 2004; Ghosh et al., 2007 and Jat et al., 2012). The introduction of legumes and oilseeds can provide a sustainable production base to the continued rice mono-cropped system, which otherwise leads to a decline in total factor productivity. Hence, research has been envisaged on identifying low water requiring alternative crops that are highly productive, resource efficient, remunerative and sustainable, to fit into rice-based cropping system for the PAP command area of Tamil Nadu, based on soil fertility, system productivity and economic returns.

\section{MATERIAL AND METHODS}

Field experiments were conducted during 20162019 in Field Number A3 of Coconut Research Station, Aliyarnagar (10⒉' 449 N; 07658' 775 E) to elicit the impact of rice-based cropping systems on soil fertility, system productivity and on economic returns. The soil is sandy loam in texture, classified taxonomically as Typic Ustropept. The bulk density of the soil is $1.35 \mathrm{Mgm}^{-3}$, particle density of $2.46 \mathrm{Mg} \mathrm{m}^{-3}$ and porosity is $45.2 \%$. The $\mathrm{pH}$ of the experimental soil is 7.96 with an electrical conductivity of 0.33 $\mathrm{dSm}^{-1}$. The major nutrients such as $\mathrm{KMnO}_{4}-\mathrm{N}$ was $242 \mathrm{~kg} \mathrm{ha}^{-1}$, Olsen P of $14.4 \mathrm{~kg} \mathrm{ha}^{-1}, \mathrm{NNH}_{4} \mathrm{OAc}-\mathrm{K}$ of $246 \mathrm{~kg} \mathrm{ha}^{-1}$ indicating the low and medium status of the nutrients respectively. The organic carbon content of the soil was medium (5.2 $\left.\mathrm{g} \mathrm{kg}^{-1}\right)$. Experiment was conducted in a Randomized Block Design with each treatment replicated four times. Five rice-based cropping systems viz., rice-sesame $\left(T_{1}\right)$, ricegroundnut $\left(T_{2}\right)$, rice-sunflower $\left(T_{3}\right)$, rice-castor $\left(T_{4}\right)$ and rice-black gram $\left(T_{5}\right)$ were evaluated for their production potential, soil fertility and economics. After the first crop of rice, without disturbing the plots, the field was prepared using a power tiller to optimum tilth and the sequential crops were raised adopting the crop management practices furnished in Table 1. The Kharif crop of rice was sown during the last week of June and harvested during October and the sequential crops were sown during October. During Kharif, the crop was irrigated to maintain a saturated moisture regime whilst Rabi crops were irrigated only at critical crop growth stages. Irrigation water was quantified through Parshall Flume placed in the field.

Table 1. Agronomic package of practices followed for crops of the sequence

\begin{tabular}{|c|c|c|c|c|c|c|c|}
\hline S.No. & Particulars & Rice & Groundnut & Sunflower & Castor & Sesame & Black gram \\
\hline 1. & Variety & $\mathrm{C050}$ & $\mathrm{CO} 7$ & CO2 hybrid & YRCH 1 & TMV 7 & ADT 5 \\
\hline 2. & Duration (days) & $130-135$ & $100-105$ & $90-95$ & $150-160$ & $80-85$ & $65-70$ \\
\hline 3. & Seed Rate $\left(\mathrm{kg} \mathrm{ha}^{-1}\right)$ & 40 & 125 & 4.0 & 5.0 & 5.0 & 20.0 \\
\hline 4. & Land Configuration & Flat Bed & Flat Bed & Ridges and Furrows & Ridges and Furrows & Flat Bed & Flat Bed \\
\hline 5. & Spacing & $(20 \times 10) \mathrm{cm}$ & $(30 \times 10) \mathrm{cm}$ & $(60 \times 30) \mathrm{cm}$ & $(150 \times 120) \mathrm{cm}$ & $(30 \times 30) \mathrm{cm}$ & $(30 \times 10) \mathrm{cm}$ \\
\hline 6. & Planting method & Transplanting & Dibbling & Dibbling & Dibbling & Sand mix & Broadcasting \\
\hline 7. & Fertilizer (NPK)/ha & $150-50-50$ & $25-50-75$ & $60-90-60$ & $90-45-45$ & $35-23-23$ & $25-50-25$ \\
\hline 8. & $\begin{array}{l}\text { Special management } \\
\text { practices }\end{array}$ & - & $\begin{array}{c}\text { Gypsum @ } 200 \\
\text { kg ha-1 on } 45 \\
\text { DAS }\end{array}$ & $\begin{array}{c}\text { Borax spray @ } 0.2 \% \\
\text { at capitulum formation } \\
\text { stage }\end{array}$ & - & $\begin{array}{c}\mathrm{MnSO}_{4} @ 5 \\
\mathrm{~kg} \mathrm{ha}^{-1}\end{array}$ & $\begin{array}{c}2 \% \text { DAP spray } \\
\text { on } 30 \text { and } 45 \\
\text { DAS }\end{array}$ \\
\hline
\end{tabular}

$107|10-12| 2$ 
To elicit the differential effect of cropping sequences on soil fertility, soil samples were collected at the end of the first crop and sequential crops. Analyses viz., $\mathrm{pH}$, electrical conductivity (Jackson, 1973), $\mathrm{KMnO}_{4^{-}} \mathrm{N}$ (Subbiah and Asija, 1956), Olsen $\mathrm{P}$ (Olsen et al., 1954), $\mathrm{NNH}_{4} \mathrm{OAc}-\mathrm{K}$ (Stanford and English, 1949) and organic carbon content (Walkley and Black, 1934) were performed adopting the standard procedures. Economics of the cropping sequences were worked out on the basis of the market price of the product and other agro-inputs. Productivity of the cropping sequences was assessed based on rice-equivalent yield. Water use efficiency was computed as the ratio of yield obtained per unit of available water (Sinclar et al., 1984). Rice equivalent yield (kg ha-1) was calculated employing the following formula

\begin{tabular}{|c|c|}
\hline Rice & Yield of the sequential crop $\left(\mathrm{kg} \mathrm{ha}^{-1}\right)$ \\
\hline Equivalent & $x$ Price of the crop (Rs. $\left.\mathrm{kg}^{-1}\right)$ \\
\hline yield & Price of rice (Rs. $\mathrm{kg}^{-1}$ ) \\
\hline
\end{tabular}

Land use efficiency (LUE) was obtained by dividing the total duration of crops in an individual cropping system by 365 days (Chuang, 1973).
Production efficiency values were obtained by dividing total production in sequence by the total duration of a cropping sequence (Tomar and Tiwari, 1990). Net returns were worked out as the difference between gross returns and the cost of cultivation. Economic efficiency (Perin et al., 1979) in terms of Rs. ha- ${ }^{-1}$ day $^{-1}$ was worked out by dividing the net returns of a cropping sequence by the total duration of the cropping sequence in a year. Pooled analysis was performed from the data accrued across three years and subjected to statistical scrutiny employing Gomez and Gomez (1984) and the results are discussed in detail based on the critical differences obtained.

\section{RESULTS AND DISCUSSION}

\section{Weather variables}

The weather variables recorded in the Agro Meteorological Observatory of Coconut Research Station, Aliyarnagar for the period 2014 - 2020 is presented in Table 2. The minimum temperature ranged from $21.5^{\circ} \mathrm{C}$ to $27.5^{\circ} \mathrm{C}$ and the maximum temperature from $35.3^{\circ} \mathrm{C}$ to $38.0^{\circ} \mathrm{C}$ in the said period.

Table 2. Weather variables recorded at Coconut Research Station, Aliyarnagar

\begin{tabular}{|c|c|c|c|c|c|c|}
\hline Year & $\begin{array}{c}\text { Max. } \\
\text { Temp. }\left({ }^{\circ} \mathrm{C}\right)\end{array}$ & $\begin{array}{c}\text { Min. } \\
\text { Temp }\left({ }^{\circ} \mathrm{C}\right)\end{array}$ & $\begin{array}{c}\text { Rainfall } \\
\text { (mm) }\end{array}$ & $\begin{array}{c}\text { Relative } \\
\text { Humidity (\%) }\end{array}$ & $\begin{array}{c}\text { Evaporation } \\
(\mathrm{mm})\end{array}$ & $\begin{array}{c}\text { Wind Velocity } \\
\text { (kmph) }\end{array}$ \\
\hline 2014 & 36.7 & 25.0 & $1054.9(83)$ & 90.8 & 5.9 & 3.1 \\
\hline 2015 & 35.3 & 22.3 & $1073.7(76)$ & 92.4 & 6.5 & 2.5 \\
\hline 2016 & 38.0 & 23.9 & $480.4(31)$ & 90.0 & 8.0 & 4.0 \\
\hline 2017 & 36.8 & 24.2 & $748.1(50)$ & 93.4 & 5.6 & 2.9 \\
\hline 2018 & 36.8 & 23.1 & $1085.5(73)$ & 96.8 & 4.8 & 2.7 \\
\hline 2019 & 38.0 & 27.5 & 896.01 (67) & 97.2 & 9.0 & 4.4 \\
\hline 2020 & 37.5 & 21.5 & $684.9(57)$ & 94.2 & 4.8 & 6.2 \\
\hline
\end{tabular}

Figures in parentheses represent the number of rainy days

Rainfall received during 2016 was $40.5 \%$ lesser than the mean annual rainfall of the region and the water levels in the reservoirs dropped down drastically forcing the farmers to abandon rice cultivation. The scenario reversed only during 2018 and thereafter again there was a dent in rainfall during 2020.

Table 3. Initial and post-harvest soil fertility status of paddy-oilseeds cropping sequence experiment

\begin{tabular}{|c|c|c|c|c|c|c|c|c|c|c|c|c|}
\hline \multirow[t]{2}{*}{ Cropping System } & \multicolumn{2}{|c|}{ pH } & \multicolumn{2}{|c|}{$\underset{\left(\mathrm{dSm} \mathbf{m}^{-1}\right)}{\mathrm{EC}}$} & \multicolumn{2}{|c|}{$\mathrm{KMnO}_{4}-\mathrm{N}$} & \multicolumn{2}{|c|}{$\begin{array}{l}\text { Olsen P } \\
\left(\mathrm{kg} \mathrm{ha}^{-1}\right)\end{array}$} & \multicolumn{2}{|c|}{$\mathrm{NNH}_{4} \mathrm{OAC}-\mathrm{K}$} & \multicolumn{2}{|c|}{$\begin{array}{l}\text { Organic carbon } \\
\qquad\left(\mathrm{g} \mathrm{kg}^{-1}\right)\end{array}$} \\
\hline & 2016 & 2019 & 2016 & 2019 & 2016 & 2019 & 2016 & 2019 & 2016 & 2019 & 2016 & 2019 \\
\hline $\mathrm{T}_{1}:$ Rice-Sesame & 7.96 & 8.04 & 0.33 & 0.41 & 248 & 196 & 14.6 & 14.0 & 246 & 214 & 4.6 & 4.6 \\
\hline $\mathrm{T}_{2}:$ Rice-Groundnut & 8.02 & 8.01 & 0.24 & 0.37 & 234 & 278 & 14.1 & 14.8 & 220 & 235 & 5.4 & 5.7 \\
\hline $\mathrm{T}_{3}:$ Rice-Sunflower & 7.87 & 7.98 & 0.24 & 0.31 & 247 & 254 & 14.4 & 14.2 & 216 & 228 & 4.6 & 4.6 \\
\hline $\mathrm{T}_{4}:$ Rice-Castor & 8.04 & 8.06 & 0.20 & 0.32 & 238 & 232 & 14.4 & 14.0 & 237 & 220 & 5.4 & 4.6 \\
\hline $\mathrm{T}_{5}:$ Rice-Black gram & 7.98 & 7.87 & 0.31 & 0.34 & 247 & 282 & 14.6 & 15.1 & 228 & 248 & 5.4 & 5.7 \\
\hline Mean & 7.96 & 7.99 & 0.33 & 0.35 & 242.8 & 253 & 14.4 & 14.4 & 246 & 229 & 5.1 & 5.0 \\
\hline S. Ed. & 0.554 & 0.618 & 0.022 & 0.02 & 18.6 & 19.5 & 1.108 & 1.12 & 17.9 & 17.4 & 0.39 & 0.39 \\
\hline$C D(P=0.05)$ & NS & NS & NS & NS & NS & 45.6 & NS & NS & NS & NS & NS & 0.9 \\
\hline
\end{tabular}




\section{Soil Fertility Status}

The initial and post-harvest soil fertility status for the period 2016 - 2019 is presented in Table 3. Compared to the initial soil fertility status during 2016, soil reaction and electrical conductivity registered a mild increase in the post-harvest soil during 2019; however no significant variation was observed between the cropping sequences adopted. It is a natural corollary that the $\mathrm{pH}$ of the soil under submergence converges to neutrality (Kar et al., 1977 and Ponnamperuma, 1978) and hence sequential crops did not impact their influence on the $\mathrm{pH}$ of the post-harvest soil. Electrical conductivity did not register significant variation among the cropping sequences adopted.

Table 4. Growth attributes of rice in rice-based cropping sequence at harvest stage (2016 -19)

\begin{tabular}{lcccc}
\hline \multicolumn{1}{c}{ Cropping system } & Plant height $\mathbf{( c m )}$ & Number of leaves per plant & Root length $\mathbf{( c m )}$ & Dry matter Production (kg ha $\mathbf{~}^{-1}$ ) \\
\hline $\mathrm{T}_{1}:$ Rice-Sesame & 92.20 & 43 & 15.85 & 10150 \\
$\mathrm{~T}_{2}:$ Rice-Groundnut & 89.75 & 41 & 15.60 & 10200 \\
$\mathrm{~T}_{3}:$ Rice-Sunflower & 94.12 & 46 & 14.33 & 10100 \\
$\mathrm{~T}_{4}:$ Rice-Castor & 87.83 & 42 & 15.75 & 10100 \\
$\mathrm{~T}_{5}:$ Rice-Black gram & 86.32 & 45 & 15.90 & 10300 \\
Mean & 90.04 & 43 & 15.49 & 10170 \\
S.Ed. & 6.79 & 3.17 & 1.17 & 760 \\
$\mathrm{CD}(\mathrm{P}=0.05)$ & $\mathrm{NS}$ & $\mathrm{NS}$ & $\mathrm{NS}$ & $\mathrm{NS}$ \\
\hline
\end{tabular}

The content of $\mathrm{KMnO}_{4}-\mathrm{N}$ was higher in the riceblack gram sequence followed by rice-groundnut and rice-sunflower sequences and was the lowest in rice-sesame sequence. The results are in proximity to the findings of Tamilezhai et al., (2018). The residual nitrogen benefits of legumes have been well documented by several workers (Ahmad et al.,
2001; Wasim et al., 2015 and Kakraliya et al., 2018). In an experiment conducted to assess the residual nitrogen benefits to rice in farmers' fields of North East Thailand, it was found that groundnut fixed $72-77 \%$ of its nitrogen amounting to $150-200 \mathrm{~kg}$ $\mathrm{N} \mathrm{ha}^{-1}$ in 106 - 119 days (Toomson et al., 1995).

Table 5. Growth at harvest, yield attributes and yield of sequential crops in rice-based cropping sequence (2016 - 19)

\begin{tabular}{lcccccc}
\hline Cropping system & $\begin{array}{c}\text { Plant population } \\
\text { per } \mathbf{~ m}^{\mathbf{2}}\end{array}$ & $\begin{array}{c}\text { Plant height } \\
\mathbf{( c m )}\end{array}$ & $\begin{array}{c}\text { Number of } \\
\text { pods per plant }\end{array}$ & $\begin{array}{c}\mathbf{1 0 0} \text { seed } \\
\text { weight (g) }\end{array}$ & $\begin{array}{c}\text { Seed / Kernel } \\
\text { yield (kg /ha) }\end{array}$ & $\begin{array}{c}\text { Haulm / Stalk } \\
\text { yield (kg /ha) }\end{array}$ \\
\hline $\mathrm{T}_{1}:$ Rice-Sesame & 10 & 153.4 & 56 & 2.30 & 870 & 2420 \\
$\mathrm{~T}_{2}:$ Rice-Groundnut & 30 & 25.0 & 23 & 30.5 & 1257 & 2828 \\
$\mathrm{~T}_{3}:$ Rice-Sunflower & 05 & 160.9 & 01 & 5.0 & 2150 & 2756 \\
$\mathrm{~T}_{4}:$ Rice-Castor & - & 82.9 & 42 & 26.0 & 1465 & 2986 \\
$\mathrm{~T}_{5}:$ Rice-Black gram & 30 & 26.2 & 23 & 3.6 & 700 & 2440 \\
\hline
\end{tabular}

In a trial on sequential cropping, nitrogen fixation by groundnut was significant and the residual $\mathrm{N}$ effect was higher on the succeeding rice crop (Senaratne and Ratnasinghe, 1995). Although the availability of phosphorus and potassium did not show any statistical superiority among the treatments in the post-harvest soil, there was mining of potassium in the soil of rice-sesame sequence. As sesame is one of the heavy feeders of nutrients (Adisu et al., 2020), there is a depression in the soil fertility status of the post-harvest soil compared to the other sequences experimented with. Organic carbon content in the post-harvest soil was higher in rice-black gram, ricegroundnut and rice-castor cropping sequences owing to the recycling of stubbles in the above systems.

\section{Growth and Yield attributes}

Plant height of rice at harvest ranged from 86.32 $\mathrm{cm}$ to $94.12 \mathrm{~cm}$, the number of leaves per plant from 41 to 46 , root length from 14.33 to $15.90 \mathrm{~cm}$ and dry matter production from 10100 to 10300 $\mathrm{kg} \mathrm{ha}^{-1}$ (Table 4). Although statistical parlance was observed among the cropping sequences on the

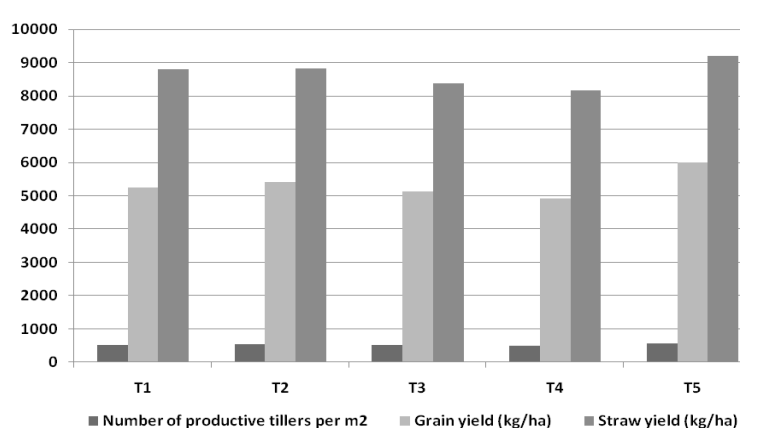

Figure 1. Yield attributes and yield of rice in ricebased cropping sequences (2016 - 19)

$107 \mid 10-12$ | 4 
above parameters, the inclusion of black gram in the system resulted in increased dry matter production of rice crops. Diverse cropping sequences adopted did not bring noteworthy differences in a number of productive tillers per plant. However, numerically higher grain yield were recorded in rice-black gram system followed by rice - groundnut system (Figure 1). An array of evidence states that the inclusion of legumes in rice based cropping system increases the productivity of rice (Ahmad et al., 2001; Hegde, 2003; Kakraliya et al., 2018, Nath et al., 2019 and Ghosh et al., 2019). Introduction of a legume in rice-based cropping system has several advantages like biological nitrogen fixation which include nutrient recycling from deeper layers, minimizing soil compaction, increasing soil organic matter and breaking pest cycles (Sanford and Hairstron, 1984; Wani et al., 1995). Thus in the present study, rice yield was higher in rice-black gram and rice-groundnut systems compared to the other nonlegume sequences experimented. Growth of the sequential crops at harvest, yield attributes and yield are presented in Table 5. As the phenology, physiology, architecture, flowering and bearing habits of the sequential crops are different, their statistical comparison will be obsolete and hence presented per se.

Table 6. Rice Equivalent Yield, Land Use Efficiency and Production Efficiencies of cropping sequences in ricebased cropping system (2016 - 19)

\begin{tabular}{lcccc}
\hline Cropping system & $\begin{array}{c}\text { REY of sequential crop } \\
\text { (kg ha }^{-1} \text { ) }\end{array}$ & $\begin{array}{c}\text { Land Use Efficiency } \\
\text { (\%) }\end{array}$ & $\begin{array}{c}\text { Production Efficiency } \\
\text { (kg ha }^{-1} \text { day }^{-1} \text { ) }\end{array}$ & $\begin{array}{c}\text { Economic Efficiency } \\
\text { (Rs. ha }^{-1} \text { day }^{-1} \text { ) }\end{array}$ \\
\hline $\mathrm{T}_{1}:$ Rice-Sesame & 1856 & 57.5 & 30.2 & 144.2 \\
$\mathrm{~T}_{2}:$ Rice-Groundnut & 5028 & 64.4 & 47.5 & 269.2 \\
$\mathrm{~T}_{3}:$ Rice -Sunflower & 5733 & 60.3 & 38.8 & 230.1 \\
$\mathrm{~T}_{4}:$ Rice-Castor & 4004 & 76.7 & 42.5 & 162.1 \\
$\mathrm{~T}_{5}:$ Rice-Black gram & 1867 & 53.4 & 40.3 & 280.0 \\
S.Ed. & 1125 & 2.64 & 1.75 & 13.7 \\
$\mathrm{CD}(\mathrm{P}=0.05)$ & 2669 & 7.19 & 5.15 & 31.8 \\
\hline
\end{tabular}

\section{Land Use Efficiency and Production Efficiency}

Rice equivalent yield and efficiencies of cropping systems are presented in Table 6. Rice equivalent yield was the highest in sunflower followed by groundnut and was the lowest in sesame, mainly due to the lower yield of sesame than the other sequential crops experimented with. Land utilization efficiency was the highest (76.7\%) in the rice-castor system and lowest (53.4\%) in rice-black gram sequence, which is mainly attributed to the long duration of castor and short duration of black gram in the field. Similar results of rice-black gram cropping sequence recording lowest land utilization efficiency were recorded by Sanjoy and Monalisa (2007). Production efficiency was the highest in the rice-groundnut system followed by the rice-castor system and was the lowest in rice-sesame system. Economic efficiency was the highest in rice-black gram system (Rs. 280 ha $^{-1}$ day $^{-1}$ ), followed by rice groundnut system (Rs. 269 ha-1 $^{-1}$ day $^{-1}$ ).

Table 7. Water Use Efficiency and Economics of rice in rice-based cropping sequences (2016 - 19)

\begin{tabular}{|c|c|c|c|c|c|c|}
\hline Cropping system & $\begin{array}{l}\text { Total water } \\
\text { used (mm) }\end{array}$ & $\begin{array}{c}\text { WUE } \\
\text { (kg/ha.mm) }\end{array}$ & $\begin{array}{c}\text { Cost of Cultivation } \\
\text { Rs/ha }\end{array}$ & $\begin{array}{c}\text { Gross returns } \\
\text { Rs/ha }\end{array}$ & $\begin{array}{l}\text { Net returns } \\
\text { Rs/ha }\end{array}$ & B : C \\
\hline $\mathrm{T}_{1}:$ Rice-Sesame & 1150 & 4.57 & 35000 & 57396 & 22396 & 1.64 \\
\hline $\mathrm{T}_{2}:$ Rice-Groundnut & 1150 & 4.71 & 35000 & 59411 & 24411 & 1.70 \\
\hline $\mathrm{T}_{3}:$ Rice-Sunflower & 1150 & 4.46 & 35000 & 55688 & 20688 & 1.59 \\
\hline $\mathrm{T}_{4}:$ Rice-Castor & 1150 & 4.28 & 35000 & 53088 & 18088 & 1.52 \\
\hline $\mathrm{T}_{5}:$ Rice-Black gram & 1150 & 5.22 & 35000 & 59604 & 24604 & 1.70 \\
\hline Mean & 1150 & 4.65 & 35000 & 58437 & 23437 & \\
\hline
\end{tabular}

\section{Water Use Efficiency and Economics}

Total water consumed was computed by summing the irrigation water applied and the effective rainfall. Effective rainfall was calculated as fifty percent of the total rainfall during the cropping period. The highest water use efficiency of rice $\left(5.22 \mathrm{~kg} \mathrm{ha}^{-1}\right.$ $\mathrm{mm}^{-1}$ ) was witnessed in rice-black gram cropping sequence followed by rice-groundnut (4.71 kg ha-1 $\left.\mathrm{mm}^{-1}\right)$ and rice-sesame $\left(4.57 \mathrm{~kg} \mathrm{ha}^{-1} \mathrm{~mm}^{-1}\right)$ systems (Table 7) which may be attributed to the higher grain yields of rice obtained in the above systems. Sureshkumar and Pandian, 2017 recorded a water use efficiency of $6.7 \mathrm{~kg} \mathrm{ha}^{-1} \mathrm{~mm}^{-1}$ in the SRI method of rice cultivation whilst lower WUE was recorded with a conventional method of rice cultivation. 
Table 8. Water Use Efficiency and Economics of sequential crops in rice-based cropping sequences (2016 -19)

\begin{tabular}{|c|c|c|c|c|c|c|}
\hline Cropping system & $\begin{array}{l}\text { Total water } \\
\text { used }(\mathrm{mm})\end{array}$ & $\begin{array}{c}\text { WUE } \\
\text { (kg/ha. mm) }\end{array}$ & $\begin{array}{c}\text { Cost of Cultivation } \\
\text { Rs/ha }\end{array}$ & $\begin{array}{c}\text { Gross returns } \\
\text { Rs/ha }\end{array}$ & $\begin{array}{l}\text { Net returns } \\
\text { Rs/ha }\end{array}$ & B : C \\
\hline $\mathrm{T}_{1}:$ Rice-Sesame & 580 & 1.50 & 32000 & 43500 & 11500 & 1.36 \\
\hline $\mathrm{T}_{2}:$ Rice-Groundnut & 380 & 3.31 & 28036 & 62850 & 34814 & 2.24 \\
\hline $\mathrm{T}_{3}:$ Rice-Sunflower & 420 & 5.12 & 31500 & 75250 & 43750 & 2.39 \\
\hline $\mathrm{T}_{4}:$ Rice-Castor & 620 & 2.36 & 28000 & 43950 & 15950 & 1.57 \\
\hline $\mathrm{T}_{5}:$ Rice-Black gram & 350 & 2.00 & 26000 & 56000 & 30000 & 2.15 \\
\hline
\end{tabular}

Although irrespective of cropping sequences, the cost of cultivation was the same for rice, gross returns were highest in rice-black gram system followed by rice -groundnut system because of the enhanced grain yield obtained in the above systems. Net returns and benefit-cost ratio was the highest in rice-black gram system followed by rice-groundnut system and was the lowest in rice-castor system compared to other systems. Patra et al. (1989) and Das and Bhanja (1996) also reported that the riceblack gram and rice-field pea relay cropping systems were the most remunerative relay cropping systems.

Table 9. Water Use Efficiency and Economics of rice-based cropping sequences (2016 - 19)

\begin{tabular}{lcccccc}
\hline \multicolumn{1}{c}{ Cropping system } & $\begin{array}{c}\text { Total water } \\
\text { used }(\mathbf{m m})\end{array}$ & $\begin{array}{c}\text { WUE } \\
\mathbf{( k g / h a . ~} \mathbf{m m})\end{array}$ & $\begin{array}{c}\text { Cost of Cultivation } \\
\mathbf{R s} / \mathbf{h a}\end{array}$ & $\begin{array}{c}\text { Gross returns } \\
\text { Rs/ha }\end{array}$ & $\begin{array}{c}\text { Net returns } \\
\text { Rs/ha }\end{array}$ & B : C \\
\hline $\mathrm{T}_{1}:$ :ice-Sesame & 1730 & 3.54 & 67000 & 100896 & 33896 & 1.51 \\
$\mathrm{~T}_{2}:$ Rice-Groundnut & 1530 & 4.36 & 63036 & 122261 & 59225 & 1.94 \\
$\mathrm{~T}_{3}:$ Rice-Sunflower & 1570 & 4.63 & 66500 & 130938 & 64438 & 1.97 \\
$\mathrm{~T}_{4}:$ Rice-Castor & 1770 & 3.61 & 63000 & 97038 & 34038 & 1.54 \\
$\mathrm{~T}_{5}:$ :Rice-Black gram & 1500 & 4.47 & 61000 & 115604 & 54604 & 1.90 \\
\hline
\end{tabular}

As far as the sequential crops are concerned, the highest water use efficiency was witnessed in sunflower $(5.12 \mathrm{~kg} / \mathrm{ha} \mathrm{mm})$ followed by groundnut $(3.31 \mathrm{~kg} / \mathrm{ha} \mathrm{mm})$ and the lowest was registered in sesame (Table 8). Net returns were the highest in the sunflower cropping system and the lowest was registered in rice-sesame system. Benefit-cost ratio was also the highest due to sequential cropping with sunflower followed by groundnut (Table 9).

\section{CONCLUSION}

Results indicated that of the cropping systems experimented with, rice-black gram and ricegroundnut systems are the most viable options for maintaining soil fertility, improving dry matter production and grain yield of the proceeding rice crop and economic efficiency of the sequences. Sequential cropping with sunflower followed by groundnut impacted its significance in registering higher rice equivalent yield, water use efficiency, net returns and benefit-cost ratio whilst the above parameters were the lowest in rice-sesame system. Amalgamating, the positive impact of the cropping sequences, rice-black gram, ricesunflower and rice-groundnut cropping sequences can be recommended for water scarce conditions of Parambikulam Aliyar Command area of Tamil Nadu.

\section{REFERENCES}

Adisu,T., Anbesse,B. and D.Tamene. 2020. Effect of nitrogen and phosphorus on yield and yield components of Sesame (Sesamum indicum L.) at Kamashi Zone of Benshangul Gumuz under Balanced Fertilizer. Adv. Tech. Biol Med., 8:276.

Ahmad,T., Hafeez,F.Y., Mahmood,T. and K.Malik. 2001. Residual effect of nitrogen fixed by mung bean (Vigna radiata) and black gram (Vigna mungo) on subsequent rice and wheat crops. Aus. J. Exp. Agric., 41: 245 - 248.

Cassman,K.G., Olk,D.C., Brouder,S.M. and B.A.Roberts. 1995. The influence of moisture regime, organic matter and root ecophysiology on the availability and acquisition of potassium: Implications for tropical lowland rice. In: Potassium in Asia. Proceedings of the $24^{\text {th }}$ International Colloquium of the International Potash Institute; Basel. Pp. 135-156.

Chuang,F.T. 1973. An analysis of change of Taiwan's cultivated land utilization for recent years. Rural Economic Div. JCRR Rep. 21, Taipei.

Das,N.R. and N.Bhanja. 1996. Effect of sowing condition on yield of paira crops grown after rainy season. Ind. J. Agron., 41(2): 334-335.

Gangwar,B., Katyal,V. and K.V.Anand. 2004. Stability and efficiency of cropping system in Chhattisgarh and Madhya Pradesh. Ind. J. Agric. Sci., 74 (10): 521-528.

Ghosh, P.K., Bandypadhyay,K.K.,Wanjari,R.H., Manna,M.C., Mishra, A.K. and M.Mohanty. 2007. Legume effect for enhancing productivity and nutrient use efficiency in major cropping systems - An Indian perspective: A review. J. Sust. Agrl., 30:61-86. 
Ghosh,P.K., Hazra,K.K., Venkatesh,M.S., Praharaj,C.S., Narendra Kumar, Chaitanya Prasad Nath, Ummed Singh and Sati Shankar Singh. 2019. Grain legume inclusion in cereal - cereal rotation increased base productivity in the long run. Exptl. Agrl., 1-17. https://doi.org/ 10.1017/ S0014479719000243.

Gomez,K.A. and A.A. Gomez. 1984. Statistical procedures for agricultural research $\left(2^{\text {nd }}\right.$ ed. $)$. John Wiley and sons, NewYork. 680p.

Government of Tamil Nadu (GoTN). 2019. Salient Statistics on Agriculture. $2^{\text {nd }}$ Edition. Agriculture Department, Secretariat, Government of Tamil Nadu, 2019. Pp. 1-380.

Hegde,D.M., Prakash Tiwari, S. and M.Rai. 2003. Crop diversification in Indian Agriculture. Agric. Situation in India., 8:351 - 354.

Jackson, M.L. 1973. Soil Chemical Analysis. Prentice Hall of India, New Delhi, P.498.

Jat,R.A., Dungrani,R.A., Arvadia, M.K. and K.L.Sahrawat. 2012. Diversification of rice (Oryza sativa L.) based cropping systems for higher productivity, resource-use efficiency and economic returns in South Gujarat, India. Archives of Agron. and Soil Sci., 58:561-572

Kakraliya,S.K., Ummed Singh, Abhishek Bohra, Choudhary,K.K., Sandeep Kumar, Ram Swaroop Meena and M.L.Jat. 2018. Nitrogen and Legumes: A Meta Analysis. In: Legumes for Soil Health and Sustainable Management. Springer, Singapore.

Kar,A.K., Rai,R. and S.F.Dhua. 1977. Redox potential and $\mathrm{pH}$ changes in cropped and fallow soil under submergence. Fert. Tech., 14: 29-31.

Kumpawat,B.S. 2001. Production potential and economics of different crop sequences. Ind. J. Agron., 46:421-424

Lampe, K. 1995. Rice Research: Food for 4 billion people. Geo J., 35 (3): 253 - 259.

Matsushima,S., Tanaka,T. and T. Hoshino. 1966. Analysis, of yield-determining process and its application to yield-prediction and culture improvement of lowland rice. LXXV, Temperature effects on tillering in case of leaves and culm, culmbases and roots being independently treated. Proc. Crop Sci. Soc. Japan. 34: 478-483.

Nath Chaitanya Prasad, Hazraab,K.K., Narendra Kumar, Praharaj Sati Shankar Singh,C.S., Ummed Singh and Narendra Pratap Singh. 2019. Including grain legume in rice-wheat cropping system improves soil organic carbon pools over time. Ecol. Engg., 129: 144 - 153.

Olk,D.C. and K.G.Cassman. 1995. Characterization of two chemically extracted humic acid fractions in relation to nutrient availability. ACIAR Proceedings No. 56. Canberra (Australia): ACIAR. P. 131-134.

Olsen,S.R., Cole,C.V., Watanabe,F.S. and L.Dean. 1954. Estimation of available phosphorus in soils by extraction with sodium bicarbonate. United States Department of Agriculture. P. 939.

Patra,S.S, Barik,T. and A.Misra. 1989. Production potential and economics of rice-based relay cropping systems . IRRI News., 13(6) : 48

Perin,R.K.,Donald,L.W., Edwards, R.M. and R.A. Jack.1979. From agronomic data for farmer recommendations. An Economic Training Manual. CIMMYT Information Bull., 27: 15-33.

Ponnamperuma, F.N. 1978. Electrochemical changes in submerged soils. In: Soils and Rice, IRRI, Los Banos, Philippines. Pp: 421 - 441.

Ray, M., Chatterjee,S., Pramanick,M., Mani,P.K., Roy, K. and K.Sengupta. 2009. Diversification of rice based cropping system and their impact on energy utilization and system production. J. Crop and Weed., 5(1): 162-165.

Sahrawat, K.L. 2004. Organic matter accumulation in submerged soils. Adv. Agron., 81:169-201.

Sanford, J.O. and J.E. Hairston. 1984. Effects of N fertilization on yield, growth and extraction of water by wheat following soybean and sorghum. Agron. J., 76: 623-27.

Sanjoy Saha and Monalisa Moharana. 2007. Production potential and economics of different rice-based relay cropping systems under rainfed shallow lowlands of coastal Orissa. Oryza., 44(2) : 134136.

Senaratne, R. and D.S. Ratnasinghe. 1995. Nitrogen fixation and beneficial effects of some grain legumes and green manure crops on rice. Biol. Fert. Soils., 19: 49-54.

Sinclar,T.R., Tanner, C.B. and J. M. Bennett. 1984. Water use efficiency in crop production. Biosci., 34: 36-40.

Sravan,U.S., Ramana Murthy,K.V. and G.S.Siva. 2015. Sustainability of rice based cropping system through pre-kharif crops. Environ. and Ecol., 33:1121-1125.

SravanU.S. and K.V.Ramana Murthy. 2018. Enhancing Productivity in Rice-Based Cropping Systems, Plant Competition in Cropping Systems, Daniel Dunea, IntechOpen, DOI: 10.5772/intechopen.76904

Stanford,G. and L.English. 1949. Use of the Flame Photometer in rapid soil tests for $\mathrm{K}$ and $\mathrm{Ca}$. Agron. J., 41(9):446-447.

Subbiah, B.V. and G.L. Asija. 1956. A rapid procedure for the estimation of available nitrogen in soils. Curr. Sci., 25: 259-260.

Subbian, P., Annadurai, K. and S.P.Palaniappan. 2000. In: Agriculture: Facts and figures, Kalyani Publishers, Ludhiana.

Suresh Kumar, R. and B.J. Pandian. 2017. Water production parameters and yield of rice affected by methods of transplanting and irrigation management practices. Int. J.Curr. Microbiol. App. Sci., 6(7): 142-148.

Tamilezhai, A., Chandra Sekaran, N. and C.Sudhalakshmi. 2018. Effect of different cropping sequences on soil nutrient status, nutrient uptake and crop yield in PAP command area of Tamil Nadu. Madras Agric. J., 105 (4-6): 170 - 175.

Tomar, S. and A.S. Tiwari. 1990. Production and economics of different crop sequences. Ind. J. Agron., 35(1/2): 30-35. 
Toomsan, B., Mc.Donagh,J.F., Limpinuntana,V. and K.E.Giller. 1995. Nitrogen fixation by groundnut and soyabean and residual nitrogen benefits to rice in farmers' fields in North East Thailand. PI. Soil., 175: $45-46$.

Walkley, A. and I.A.Black. 1934. An examination of the Degtjareff mathod for determining soil organic matter, and a proposed modification of the chromic acid titration method. Soil Sci., 37(1): 29-38.

Wani, S.P., Rupela, O.P. and K.K. Lee. 1995. Sustainable agriculture in the semi-arid tropics through biological nitrogen fixation in grain legumes. PI. Soil., 174: 29-49.

Wasim Ali, Amanullah Jan, Akhtar Hassan, Aqleem Abbas, Altaf Hussain, Murtaza Ali, Syed Ali Zuhair and Ashraf Hussian. 2015. Residual effect of preceding legumes and nitrogen levels on subsequent maize. Int. J. Agron. and Agrl. Res., 7(1): $78-85$.

Yoshida S. 1978. Tropical Climate and Its Influence on Rice. Research Paper Series No. 20. International Rice Research Institute, Los Baños, Philippines. 